\title{
The Importance of excretion by Chironomus larvae on the internal loads of nitrogen and phosphorus in a small eutrophic urban reservoir
}

\author{
Henry, R. $^{\mathrm{a}}{ }^{*}$ and Santos, $C M{ }^{\mathrm{b}}$ \\ aDepartamento de Zoologia, Instituto de Biociências, Universidade Estadual Paulista - UNESP, \\ CP 510, CEP 18618-000, Botucatu, SP, Brazil \\ bDepartamento de Oceanografia e Limnologia, Centro de Biociências, \\ Universidade Federal do Rio Grande do Norte - UFRN, \\ Praia da Mãe Luiza, s/n., Via Costeira, CEP 59014-100 Natal, RN, Brazil \\ *e-mail: rhenry@ibb.unesp.br \\ Received December 4, 2006 - Accepted February 2, 2007 - Distributed May 31, 2008
}

(With 2 figures)

\begin{abstract}
Measurements of ammonium and phosphate excretion by the Chironomus larvae were conducted in order to evaluate the importance of these chironomids for the internal loads of a small eutrophic urban reservoir. Ammonium and phosphate excretion rates by Chironomus larvae of small size $(6-10 \mathrm{~mm}$ total length) were significantly higher than those of the Chironomids having medium $(9-11 \mathrm{~mm})$ and large $(11-16 \mathrm{~mm})$ sizes. A dependence in relation to temperature was recorded for the ammonium and phosphate excretions that was significantly higher at $25{ }^{\circ} \mathrm{C}$ than at 20 and $15^{\circ} \mathrm{C}$. Through a linear relation between biomass (dry weight) and total length and, between excretion and biomass and, data on chironomids densities, after an intense sampling in 33 sites distributed all along the reservoir bottom, the mean phosphate and ammonium excretion rates corresponded to 2,014 $\pm 5,134 \mu \mathrm{g} \cdot \mathrm{m}^{-2} /$ day and 1,643 $\pm 3,974 \mu \mathrm{g} \cdot \mathrm{m}^{-2} / \mathrm{day}$, respectively. Considering the mean biomass $\left(34 \mathrm{mg} \cdot \mathrm{m}^{-2}\right)$ of Chironomus, the lake area $\left(88,156 \mathrm{~m}^{2}\right)$ and the mean excretion rates, the contribution of benthic chironomids to the internal loads would be $181 \mathrm{KgP}$ and $147 \mathrm{KgN}$. for the sampling months (October-November 1998). These values showed that the internal loads by excretion from Chironomus larvae correspond to approximately $33 \%$ of the external loads of phosphorus in the lake and, in the case of nitrogen, to only $5 \%$.
\end{abstract}

Keywords: excretion, Chironomus, internal load, reservoir, nutrients.

\section{Excreção por quironomídeos em reservatório urbano}

\section{Resumo}

Medidas de excreção de amônia e fosfato por larvas de Chironomus foram executadas com a finalidade de avaliar a importância desses quironomídeos nas cargas internas de um pequeno reservatório urbano eutrófico. Taxas de excreção de amônia e fosfato significativamente mais elevadas foram encontradas nas larvas de Chironomus de pequeno (6-10 mm) tamanho, em relação às de tamanho médio $(9-11 \mathrm{~mm})$ e grande $(11-16 \mathrm{~mm})$. Uma dependência em relação à temperatura foi registrada para a excreção de amônia e fosfato, significativamente mais alta a $25^{\circ} \mathrm{C}$ do que a 20 e $15^{\circ} \mathrm{C}$. Depois da obtenção das relações lineares entre biomassa (peso seco) e comprimento total e excreção com biomassa e dos dados de densidade de quironomídeos, após amostragem em 33 pontos distribuídos por todo o reservatório, foi possível estimar uma taxa média de excreção de fosfato de $2014 \pm 5134 \mu \mathrm{g} \cdot \mathrm{m}^{-2} / \mathrm{dia}$ e, de amônia em $1643 \pm 3974 \mu \mathrm{g} \cdot \mathrm{m}^{-2} / \mathrm{dia}$. Considerando a biomassa média $\left(34 \mathrm{mg} \cdot \mathrm{m}^{-2}\right)$ de quironomídeos, a área do lago $\left(88.156 \mathrm{~m}^{2}\right)$ e as taxas médias de excreção, a contribuição dos quironomídeos bênticos para as cargas internas seria de $181 \mathrm{KgP}$ e $147 \mathrm{KgN}$, para o mês da amostragem (outubro-novembro de 1998). Esses valores mostraram que as cargas internas por excreção pelas larvas de Chironomus correspondem aproximadamente a $33 \%$ das cargas externas de fósforo para o lago e, somente $5 \%$ no caso de nitrogênio.

Palavras-chave: excreção, Chironomus, carga interna, reservatório, nutrientes.

\section{Introduction}

Benthic invertebrates play an important role in the ecology of aquatic ecosystems. Bottom organisms increase the velocity of decomposition of particulate matter, breaking up the litter of riparian vegetation in lotic environments and of aquatic macrophytes in the littoral zone of lacustrine ecosystems (Stripari and Henry, 2002; Henry and Stripari, 2005). Benthic species release nutrients that are dissolved by their feeding activities, excretion and burrowing into sediments (Covich et al., 1999; Vanni, 2002). Benthic fauna are predators that control the density and size of their prey and are also a source of food for other consumers such as terrestrial and aquatic vertebrates, namely birds and fish. Finally, benthic invertebrates accelerate the transfer process of nutrients from interstitial 
water between sediment particles to a layer immediately above the water-sediment interface (Covich et al., 1999). Thus, bottom organisms participate significantly in the internal load of nutrients, one of the important processes in the mass balance of lakes and reservoirs.

Aquatic animals play a significant role in the recycling of nutrients through an active process of release (excretion) or though nutrient translocation. According to Vanni (2002), translocation differs from excretion in that, in the former process, the nutrients move through physical frontiers or by physical processes that restrain their movements (for instance, the water-sediment interface, the thermocline and the water's downstream flow). The fastest way for nutrients to become available in water is through the excretion of nitrogen and phosphorus in the inorganic compounds by aquatic organisms.

Fish, as top predators in food webs, contain large amounts of phosphorus in their bodies and are responsible, in most cases, for the translocation of this element and for its recycling - through excretion in lacustrine environments (Anderson et al., 1988). Persson (1997) demonstrated that the excretion of phosphorus by two dominant fish species (Rutilus rutilus (Linnaeus, 1758) and Abranis brama (Linnaeus, 1758)) in a eutrophic lake (Finjasjon Lake, Sweden) presented the same magnitude of external load, and that it corresponded to about $40 \%$ of the total internal load. According to Schaus et al. (1997), a detritivorous fish (Dorosoma cepedianum (Lesueur, 1818)) of a eutrophic reservoir (Acton Lake, Ohio, USA) contributes with about one third of the total inorganic dissolved nitrogen introduced by the reservoir's tributaries, and the $\mathrm{P}$ released exceeds the external inputs. The bioturbation produced by Gymnocephalus cernuus (Linnaeus, 1758), a highly specialized detritivorous fish from a mesotrophic lake (Lake Pyhäjärvi, southeastern Finland), feeding exclusively on chironomids and other invertebrates, significantly increased total phosphorus, dissolved $\mathrm{PO}_{4}^{3-}$, total nitrogen, $\mathrm{NH}_{4}-\mathrm{N}$ concentrations and water turbidity under experimental conditions (Taivainen et al., 2005).

The action of benthic invertebrates is extremely important in the nutrient fluxes of lakes and reservoirs (Anderson et al., 1988). Their participation in recycling by excretion depends on their composition, biomass, density, water temperature and oxygen content (Gallep, 1979; Granéli, 1979; Gardner et al., 1981; 1983; Fukuhara and Yasuda, 1985; 1989; Starkel, 1985; Tatrai, 1986; Fukuhara and Sakamoto, 1987). Devine and Vanni (2002) showed that phosphorus and nitrogen excretion rates by the benthic invertebrates in a eutrophic reservoir presented a higher variability as a function of the organisms' biomass and temperature than as a function of the species' composition. Spatial (as a function of oxygen content at the water-sediment interface) and temporal differences (higher in June and July in summer) were also found in the nitrogen and phosphorus released by benthic invertebrates.

This paper reports on a quantitative analysis of ammonium and phosphate excretion rates by Chironomus and discusses the importance of chironomid assemblies in the internal loads of nitrogen and phosphorus of a small urban reservoir (Lake Garças, São Paulo, Brazil).

\section{Material and Methods}

\subsection{The study area}

Lake Garças is located in the Biological Reserve of the Fontes do Ipiranga State Park $\left(23^{\circ} 38^{\prime} \mathrm{S}\right.$ and $46^{\circ} 37^{\prime} \mathrm{W}$ ) in the southern region of the municipality of São Paulo (Figure 1). Santos and Funari (2002) classified the regional climate as humid, mesothermic, without water deficiency and with an excess of water in summer. The mean annual rainfall is $1,368 \mathrm{~mm}$; the mean air temperature in the coldest month of the year (July) is $15.0{ }^{\circ} \mathrm{C}$ and the temperature in the hottest months (January - February) ranges from $21.4-21.6{ }^{\circ} \mathrm{C}$. Lake Garças has a surface area of $88,156 \mathrm{~m}^{2}$; a maximum depth of $4.7 \mathrm{~m}$ and a theoretical mean annual residence time of 68 days (Bicudo, D. et al., 2002). Lake Garças is thermally stratified and presents an oxygen hypolimnetic deficit from October to February, and is isothermic in March-April and August-September (Henry, 1999; Bicudo, D. et al., 2002). An evaluation of the total phosphorus (TP) and nitrogen (TN) contents in the water at the bottom of the lake in OctoberNovember 1998 revealed mean concentrations of $147 \pm$ 103 SD $\mu \mathrm{gTP} . \mathrm{L}^{-1}$ (coefficient of variation - C.V. $=70 \%$ ) and $2,169 \pm 823 \mathrm{SD} \mu \mathrm{gTN} . \mathrm{L}^{-1}$ (C.V. $=38 \%$ ), while the mean sediment values were $900 \pm 765 \mathrm{SD} \mu \mathrm{gTP} \mathrm{gDW}^{-1}$ $(\mathrm{C} . \mathrm{V} .=85 \%)$ and $5,191 \pm 2,290 \mathrm{SD} \mu \mathrm{gTN} \cdot \mathrm{gDW}^{-1}$ (C.V. $=44 \%)$ in 20 sampling sites of the lake. Annual loads (from January to December 1997) of the total phosphorus and nitrogen introduced by the inflowing water from seven tributaries corresponded to $6,520 \mathrm{KgP}$ and $37,157 \mathrm{KgN}$ (Henry et al., 2004). High retention of nitrogen (85\% of the total) and phosphorus (61\% of the total) is a condition of the lake (Henry et al., 2004). Based on the modified trophic state index proposed by Toledo et al. (1983), the lake was initially classified as a eutrophic-hypereutrophic ecosystem (Nogueira and Ramirez, 1998; Mercante and Tucci-Moura, 1999; Bicudo, D. et al., 2002), before it was overturn by an excessive growth of Eichhornia crassipes (Mart.) Solms, a floating macrophyte. During the phase of high coverage of this aquatic plant on the surface of Lake Garças, the ecosystem was classified as eutrophic (Bicudo et al., 2006). After the mechanical removal of E. crassipes, the lake developed a highly hypereutrophic condition.

\subsection{Sampling of the benthic fauna}

An earlier study by Santos (2002) identified three major areas on the bottom of Lake Garças, in terms of the granulometric composition and organic matter content of the sediment and the lake's depth. a) Area 1 can be considered homogeneous with respect to sediment composition, presenting great variability in depth; b) Area 2 presents an intermediate condition in terms of 

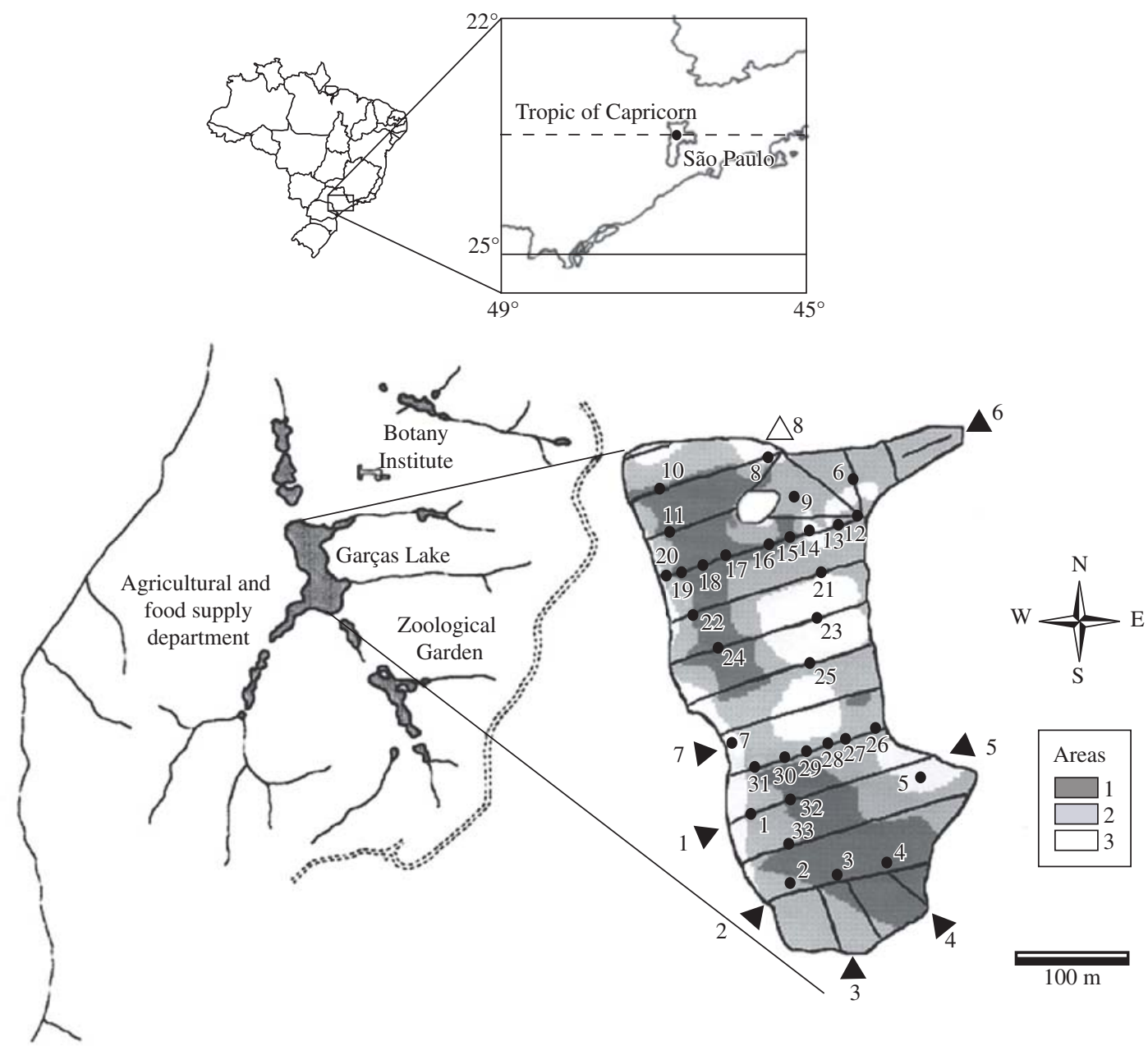

Figure 1. Lake Garças in the Fontes do Ipiranga State Park (São Paulo, Brazil). At the right site: the three different areas (areas 1, 2 and 3) in the bottom of Lake Garças (description see the text); internal to the lake, the sampling sites (1-33) and external to lake, the tributaries (1 to 7) and the downstream flux (8).

sediment and depth; and c) Area 3 can be considered homogeneous in depth but heterogeneous in terms of sediment composition (Figure 1).

A total of 33 sampling sites was selected and distributed proportionally to the extent of the three areas of lake bottom (36, 49 and $15 \%$ of the total of sampling sites in areas 1, 2 and 3, respectively). Three sediment samples were collected at each station, using a Peterson dredge (area: $367.5 \mathrm{~cm}^{2}$ ). The samples were then fixed with formaldehyde $4 \%$, dyed with floxin B (Masson and Yevich, 1967) and sorted through a $250 \mu \mathrm{m}$ mesh net. The organisms were identified based on the keys of Merrit and Cummins (1996), Epler (1992), TrivinhoStrixino and Strixino (1995), and Brinkhurst and Marchese (1989). In this paper, we will present only the Chironomidae density data (ind. $\mathrm{m}^{-2}$ ), using the cumulative value of the three sampling units.

\subsection{Excretion experiment}

Chironomidae larvae (mostly of the Chironomus genus) were sampled beside the inlet of tributary 5 into Lake Garças (Figure 1), by agitation of bottom particles and dispersion of leaf fragments, collecting them in a $250 \mu \mathrm{m}$ mesh net placed against the water flux. In the laboratory, the organisms were kept in darkness and at a controlled temperature in Marconi climatic chambers for a 12 hour acclimation period.

Excretion was measured based on the difference in ammonium and phosphate concentrations (determined according to Koroleff, 1976 and Strickland and Parsons, 1960 , respectively) after 5 hours of incubation of the organisms in test tubes, the time required to obtain reliable data (Fukuhara and Yasuda, 1989). The excretion rates, expressed by dry weight of organisms and by day $\left(\mu \mathrm{gNH}_{4}^{+}-\mathrm{N} . \mathrm{mg} \mathrm{DW}^{-1} \cdot \mathrm{d}^{-1}\right.$ and $\left.\mu \mathrm{gPO}_{4}^{3}-\mathrm{P} . \mathrm{mg} \mathrm{DW}^{-1} \cdot \mathrm{d}^{-1}\right)$, 
were measured in two types of water (filtered lake water diluted with deionized water in a 1:3 ratio, and artificial water prepared with $20 \mathrm{mg} \mathrm{CaCl} 2.2 \mathrm{H}_{2} \mathrm{O}, 10 \mathrm{mg} \mathrm{\textrm {MSO } _ { 4 }}$ and $20 \mathrm{mg} \mathrm{NaHCO}$ per liter of deionized water, according to Lehman, 1980).

Two factors were tested: a) the size of the organisms (small, medium-sized and large individuals having a total length of 6 to $10 \mathrm{~mm}, 9$ to $11 \mathrm{~mm}$ and 11 to $16 \mathrm{~mm}$, respectively); and b) the temperature $\left(15,20\right.$ and $25{ }^{\circ} \mathrm{C}$ - the amplitude of water temperature variation at the bottom of the lake during the year). Five test tubes containing 30 individuals of each size class in $50 \mathrm{~mL}$ of lake water diluted and, in $50 \mathrm{~mL}$ of artificial water were used in each treatment.

At the end of the experiments, the Chironomus larvae were measured (total length) and the biomass (dry weight) computed.

To find a relation between biomass (dry weight) and total length, 40 organisms, 30 having a total length of 6 to $16 \mathrm{~mm}$ and 10 with a total length of 13 to $17 \mathrm{~mm}$, were oven-dried at $110{ }^{\circ} \mathrm{C}$ for 2 hours.

Regression equations between excretion rates and chironomids biomass were obtained (Snedecor and Cochran, 1978), based on the estimated biomass in each tube and the respective phosphate and ammonium excretion rates. To evaluate the excretion rate of Chironomidae in each sampling site, first the organisms were measured, then the biomass (dry weight) was estimated (from the biomass $\mathrm{X}$ length regression equation), and lastly the excretion rate was calculated (based on the excretion $\mathrm{X}$ biomass regression equations).

An ANOVA test was applied (Statistica, 1993) to ascertain the probable differences in Chironomus phosphate and ammonium excretion rates as a function of size, water temperature and quality. Levene's test was employed to test the homogeneity of variances (Vieira, 1998). Tukey's test was applied to compare each pair of the different variables.

\section{Results}

Chironomidae larvae were found in only 20 of the 33 benthic fauna sampling sites. A substantial spatial variability (Coefficient of variation - C.V. $=217 \%$ ) in larvae densities $\left(\overline{\mathrm{X}}=1,398 \pm 3,031 \mathrm{SD}\right.$ ind. $\left.\mathrm{m}^{-2}\right)$ was recorded in the Lake Garças (Table 1). Chironomids were not found in area 1 (homogeneous sediment composition and highly variable depth).

Biomass values ranged from 0.4 to $6.46 \mathrm{mg} \mathrm{DW}$ $(\overline{\mathrm{X}}=2.2 \mathrm{mg} \mathrm{DW} ; \mathrm{n}=40)$ for organisms having lengths ranging from 6 to $17 \mathrm{~mm}$ length. The relation between biomass (DW, in $\mathrm{mg}$ ) and total length (TL, in $\mathrm{mm}$ ) of the Chironomus can be expressed as:

$\log \mathrm{DW}=3.7228 \log \mathrm{TL}-3.5542(\mathrm{r}=0.91)$

Significant differences $(\mathrm{F}=20.34 ; \mathrm{P}<0.05)$ were found in phosphate excretion rates as a function of Chironomus larvae size (Table 2). Tukey's test revealed that small organisms presented significantly higher excretion rates than the other two size classes of chironomids. With regard to temperature, the highest excretion rate, which was measured at $25{ }^{\circ} \mathrm{C}$, was significantly higher $(\mathrm{F}=12.69 ; \mathrm{P}<0.05)$ than at 15 and $20^{\circ} \mathrm{C}($ Table 2$)$.

The ammonium excretion rates of the large organisms were significantly lower $(\mathrm{F}=8.54 ; \mathrm{P}<0.05)$ than those of the other two size classes (Table 3 ). As for temperature, the lowest excretion rate $(\mathrm{F}=4.41 ; \mathrm{P}<0.05)$ occurred at $15{ }^{\circ} \mathrm{C}$, and was significantly lower than the excretion rates at 20 and $25^{\circ} \mathrm{C}$ (Table 3 ).

Figure 2 shows the relationships between phosphate and ammonium excretion rates and Chironomidae larvae biomasses (dry weight) at three different temperatures, and Table 4 presents the linear regression equations.

The total biomass and the amount of phosphate and ammonium excreted by each site (Table 1) were estimated based on the values of Chironomidae larvae density in each sampling site (Table 1), the total measured length of all the organisms found at each site, the relation between biomass, and total length (Equation 1), and the linear regression equations of excretion rates as a function of biomass (Table 4). The mean biomass was $34 \pm$ 93SD mgDW. $\mathrm{m}^{-2}$, and varied greatly between sampling sites $(\mathrm{C} . \mathrm{V} .=274 \% ; \mathrm{n}=20)$. The mean phosphate excretion rate was $2,014 \pm 5,134 \mathrm{SD} \mu \mathrm{g} \cdot \mathrm{m}^{-2} /$ day, with a high variability $(\mathrm{C} . \mathrm{V} .=255 \%)$. The mean ammonium excretion rate reached $1,643 \pm 3,974 \mathrm{SD} \mu \mathrm{g} . \mathrm{m}^{-2} /$ day (C.V. $=242 \%)$.

\section{Discussion}

The biomass of Chironomus individuals in Lake Garças showed a higher mean value than that recorded by Tokeshi (1995) for several Chironomidae species (from 0.1 to $1.0 \mathrm{~g} \mathrm{DW}$ ), but was similar to the data reported by Fukuhara and Yasuda $(1985,1989)$ and Tatrai (1986). However, at the populational level, the chironomid biomass showed different values even in the same densities (e.g., in sites 2, 8, 14 and 33, Table 1). These differences can be attributed to the peculiar size structure of the invertebrates collected at these sampling sites.

Only the ammonium excretion rates of Chironomidae larvae presented significant differences $(\mathrm{P}<0.05)$ when measured in the two types of water used here (filtered lake water and artificial water). A similar study conducted by Fukuhara and Yasuda (1989) showed that the ammonium excretion rate was higher in the artificial water, but no significant difference $(\mathrm{P}<0.01)$ was found between the two culture mediums used in the tests. As in our case of the chironomids of Lake Garças, Fukuhara and Yasuda (1985) detected no differences in the phosphorus excretion rates of organisms from eutrophic lakes in Japan kept in natural (filtered lake water) and artificial water. Napela et al. (1983) found no difference between the phosphorus excretion rates of chironomids and oligochaetas in lake and distilled water, but observed a slight increase in amphipods excretions in distilled water. Thus, the eutrophic condition of the water of these lakes and of the 
Table 1. Chironomidae density (org. $\left.\mathrm{m}^{-2}\right)$ and biomass $\left(\mathrm{mgDW} \cdot \mathrm{m}^{-2}\right)$, and excreted phosphate and ammonia rates $\left(\mu \mathrm{g} \cdot \mathrm{d}^{-1} \cdot \mathrm{m}^{-2}\right)$ in Lake Garças.

\begin{tabular}{crrrr}
\hline Sites & Density & Biomass & Excreted phosphate & Excreted ammonia \\
\hline 1 & 9 & 0.001 & 35 & 31 \\
2 & 54 & 0.45 & 82 & 75 \\
3 & 63 & 0.56 & 28 & 28 \\
4 & 27 & 0.08 & 18 & 18 \\
5 & 2,730 & 38.03 & 2,501 & 2,327 \\
6 & 36 & 0.09 & 410 & 316 \\
7 & 399 & 4.60 & 75 & 86 \\
8 & 54 & 2.47 & 82 & 74 \\
12 & 5,632 & 35.06 & 20,684 & 15,191 \\
13 & 399 & 30.32 & 57 & 63 \\
14 & 54 & 5.54 & 1 & 2 \\
20 & 1,270 & 14.91 & 1,638 & 1,414 \\
21 & 807 & 15.94 & 696 & 666 \\
23 & 154 & 22.82 & 19 & 20 \\
25 & 798 & 11.39 & 500 & 491 \\
26 & 12,907 & 424.03 & 11,951 & 10,670 \\
27 & 2,113 & 38.35 & 1,103 & 1,091 \\
28 & 399 & 33.58 & 19 & 24 \\
32 & 9 & 0.05 & 1 & 2 \\
33 & 54 & 0.70 & 371 & 270 \\
\hline
\end{tabular}

Table 2. Mean $(\overline{\mathrm{X}})$ and standard deviation (SD) of phosphate excretion rates $\left(\mu \mathrm{gPO}_{4}^{3-}-\mathrm{P} \mathrm{mgDW}{ }^{-1} \cdot \mathrm{d}^{-1}\right)$ as a function of temperature and size of Chironomus ( $\mathrm{S}=$ small; $\mathrm{M}=$ mean; and $\mathrm{G}=$ great organisms) in two types of water.

\begin{tabular}{ccccccccc}
\hline Water type & Size & $\overline{\mathbf{X}}$ & SD & $\mathbf{n}$ & Temperature $\left({ }^{\circ} \mathbf{C}\right)$ & $\overline{\mathbf{X}}$ & SD & $\mathbf{n}$ \\
\hline Lake water & $\mathrm{S}$ & 3.06 & 2.39 & 15 & 15 & 1.69 & 1.25 & 21 \\
& $\mathrm{M}$ & 1.34 & 0.94 & 23 & 20 & 1.18 & 1.07 & 24 \\
& $\mathrm{G}$ & 0.80 & 0.75 & 17 & 25 & 2.66 & 2.97 & 10 \\
Artificial water & $\mathrm{S}$ & 2.95 & 2.37 & 7 & 15 & 0.88 & 0.64 & 9 \\
& $\mathrm{M}$ & 1.39 & 1.40 & 10 & 20 & 1.28 & 1.42 & 8 \\
& $\mathrm{G}$ & 1.02 & 0.85 & 7 & 25 & 3.36 & 2.11 & 7 \\
\hline
\end{tabular}

Table 3. Mean $(\overline{\mathrm{X}})$ and standard deviation (SD) of ammonia excretion rates $\left(\mu \mathrm{gNH}_{4}^{+}-\mathrm{N} \cdot \mathrm{mgDW}^{-1} \cdot \mathrm{d}^{-1}\right)$ as a function of temperature and size of Chironomus ( $\mathrm{S}=$ small; $\mathrm{M}=$ mean; and $\mathrm{G}=$ great organisms) in two types of water.

\begin{tabular}{ccccccccc}
\hline Water type & Size & $\overline{\mathbf{X}}$ & SD & $\mathbf{n}$ & Temperature $\left({ }^{\circ} \mathbf{C}\right)$ & $\overline{\mathbf{X}}$ & SD & $\mathbf{n}$ \\
\hline Lake water & $\mathrm{S}$ & 2.06 & 1.40 & 15 & 15 & 1.17 & 0.95 & 21 \\
& $\mathrm{M}$ & 2.25 & 1.57 & 23 & 20 & 2.36 & 2.29 & 24 \\
& $\mathrm{G}$ & 0.73 & 0.79 & 17 & 25 & 1.39 & 1.35 & 10 \\
Artificial water & $\mathrm{S}$ & 6.47 & 2.93 & 7 & 15 & 3.29 & 1.73 & 9 \\
& $\mathrm{M}$ & 4.39 & 2.30 & 10 & 20 & 4.49 & 3.18 & 8 \\
& $\mathrm{G}$ & 3.18 & 2.07 & 7 & 25 & 6.56 & 2.11 & 7 \\
\hline
\end{tabular}

Lake Garças (Nogueira and Ramirez, 1998; Mercante and Tucci-Moura, 1999; Bicudo, D. et al., 2002) did not affect the measurements of phosphorus and ammonium excreted by chironomids, since no significant differences were found in our comparison of the two types of water.
Differences in excretion rates in the different size classes revealed biological differences in each phase of the life cycle of Chironomus In this study, the excretion rates were measured in very young individuals, in the intermediate phase and, in organisms nearing the pupa 

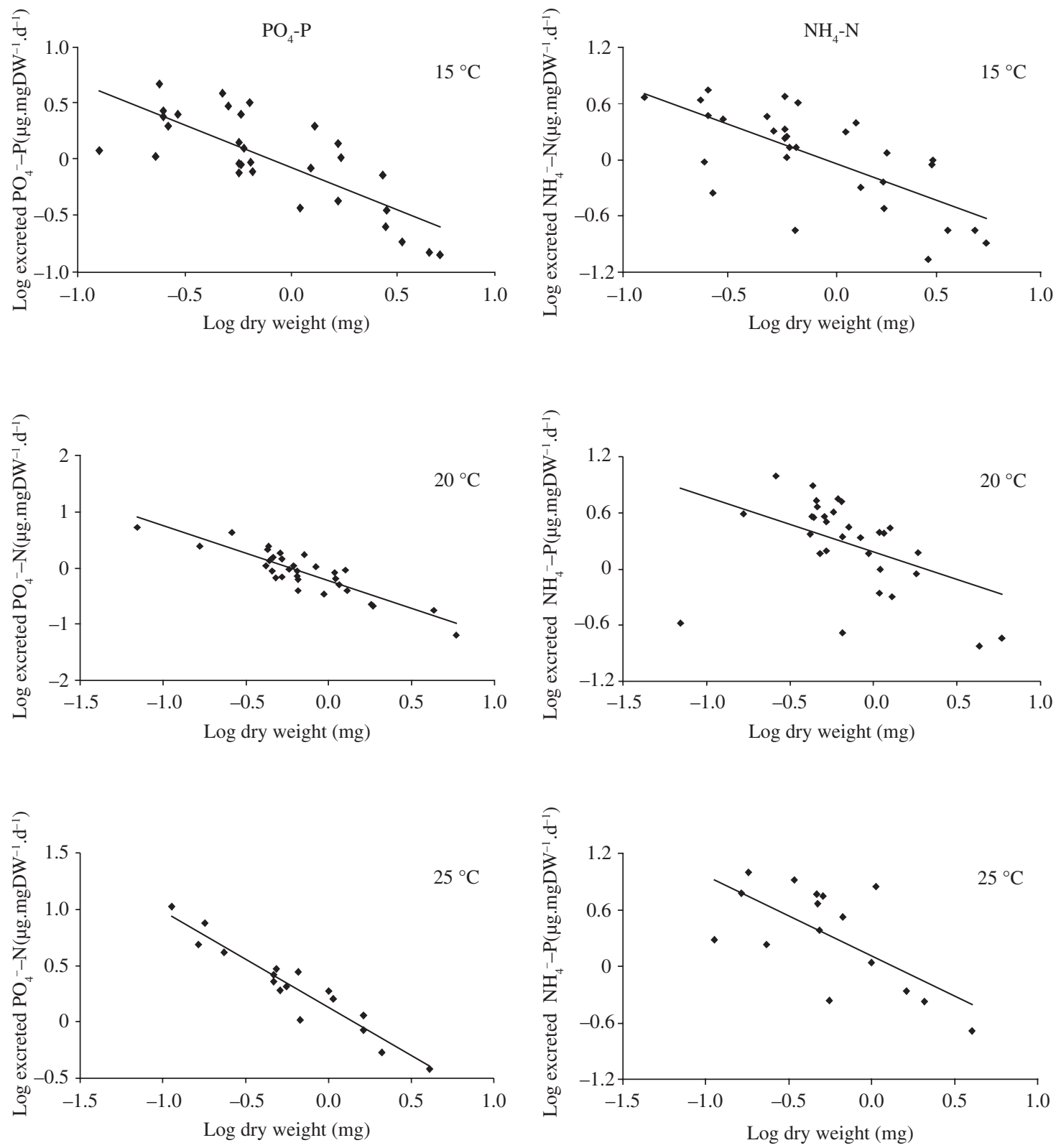

Figure 2. Relationships between phosphate and ammonium excretion rates and Chironomus larvae biomasses at three different temperatures.

Table 4. Regression equations of phosphate and ammonia excretion rates $\left(\mu \mathrm{g} \cdot \mathrm{mgDW} \cdot \mathrm{d}^{-1}\right)$ of Chironomidae larvae as a function of temperature.

\begin{tabular}{cclc}
\hline Excretion & Temperature $\left({ }^{\circ} \mathbf{C}\right)$ & Linear regression equations & r \\
\hline Phosphate & 15 & $\log \mathrm{P}=-0.7401 \log \mathrm{DW}-0.0577$ & 0.77 \\
& 20 & $\log \mathrm{P}=-0.9826 \log \mathrm{WW}-0.2312$ & 0.88 \\
& 25 & $\log \mathrm{P}=-0.8524 \log \mathrm{DW}+0.1329$ & 0.97 \\
\multirow{3}{*}{ Ammonia } & 15 & $\log \mathrm{N}=-0.8161 \log \mathrm{WW}-0.02443$ & 0.69 \\
& 20 & $\log \mathrm{N}=-0.5884 \log \mathrm{DW}+0.1843$ & 0.44 \\
& 25 & $\log \mathrm{N}=-0.8528 \log \mathrm{WW}+0.1101$ & 0.67 \\
\hline
\end{tabular}


phase. In the latter, the organisms begin their morphological transformation into the pupa phase, and a minor energetic consumption and nutrient retention probably occurs until they reach the adult phase, so a reduction in excretory activity is expected. In fact, our comparison of small and large organisms revealed significant differences in the concentrations of excreted phosphate and ammonium. Variations in ammonium and phosphate excretion rates as a function of chironomid size were also observed by Fukuhara and Yasuda $(1985,1989)$.

In addition to differences in the excretion rates of organisms of different size classes, variations can also occur in the amounts excreted by species of the same genus. Gallep (1979) showed that individuals of Chironomus tentans (Fabricius, 1805) (of large size) presented higher phosphorus excretion rates than did Chironomus riparius (Meigen, 1804) organisms (of small size).

Fukuhara and Yasuda $(1985,1989)$ and Gallep (1979) reported a positive correlation between ammonium and phosphate excretion rates and temperature. In a study conducted in Lake Suwa (Japan), Fukuhara and Yasuda (1985) found that the phosphorus excretion rates of 4 different species (Chironomus plumosus (Linnaeus, 1758), Tokunagayusurika akamusi (Tokunaga), Chaoborus flavicans (Meigen) and Limnodrilus spp. (Claparede, 1862)) increased with rising temperature. Also, Gardner et al. (1983) reported an increase of nitrogen release with increasing temperature in Chironomidae and Tubificidae organisms. With regard to the phosphorus excreted by Chironomus larvae measured at $20{ }^{\circ} \mathrm{C}$ and at $5{ }^{\circ} \mathrm{C}$ after 24 hours of incubation, the data of Gardner et al. (1981) were below the expected values, using as a criterion a $\mathrm{Q}_{10}$ corresponding to 2. Gallep (1979) showed that the phosphorus release rate of Chironomus tentans measured at $20^{\circ} \mathrm{C}$ was significantly higher (9 to 10 -fold) than at $10^{\circ} \mathrm{C}$. Comparing the excretory activity of ammonium by Chironomus larvae, Tatrai (1986) showed that an increase in temperature from 10 to $20^{\circ} \mathrm{C}$ led to an increase corresponding to 5 to 20 times in the ammonium release, depending on the density of the chironomids. In a revision paper, Vanni (2002) mentioned that the nutrient release rates of aquatic animals follow the same pattern as that of the $\mathrm{Q}_{10}$ values of other metabolic processes, ranging from 1.5 to 2.5. Our data show that, with an increase of $10{ }^{\circ} \mathrm{C}$, the $\mathrm{Q}_{10}$ values for phosphate excretion ranged from 1.6 (in filtered lake water) to 3.8 (in artificial water), while the $\mathrm{Q}_{10}$ values for ammonium release ranged from 1.2 (lake water) to 2.0 (artificial water).

Some additional information is still needed concerning the period of highest excretory activity by chironomids in tropical regions. The nitrogen release did not occur continuously but in bursts, with a greater hourly frequency at $20^{\circ} \mathrm{C}$ than at $10{ }^{\circ} \mathrm{C}$ (Gardner et al., 1983). Fukuhara and Yasuda (1989) reported that the ammonium excretion rates of Chironomus plumosus organisms increase as a function of incubation time, stabilizing after 20 hours. These authors concluded that a 5-hour interval between the beginning and the end of the experi- ment sufficed to measure the excretion rates. Since water temperature in tropical regions can vary greatly in a short period of time during the nictemeral cycle, the excretion rates obtained after 5 hours of incubation (as was the case with the organisms from Lake Garças) may not adequately indicate the importance of chironomids in the recycling of nutrients, because the excretory activity probably follows a morning, afternoon and night rhythms.

According to Vanni (2002), N:P excretion by animals is a function of the imbalance between the N:P ratios in their bodies and in food. An individual with a low body $\mathrm{N}: \mathrm{P}$ ratio would release nutrients in a higher $\mathrm{N}: \mathrm{P}$ ratio when compared with an organism with a high body $\mathrm{N}: \mathrm{P}$ ratio, if both feed from the same food resource. The $\mathrm{NH}_{4}^{+}: \mathrm{PO}_{4}^{3-}$ ratios of the amounts excreted by chironomids ranged from 14 to 21 (Gardner et al., 1983; Tatrai, 1986; Fukuhara and Yasuda, 1989). However, our data presented extremely low values (0.5-3.7), leading us to assume that the Chironomus organisms used in our experiments presented a high body N:P ratio and, thus, the amounts of excreted ammonium and phosphate were low. In fact, a comparative analysis of the literature (Granéli, 1979; Gallep, 1979; Tatrai, 1986; Devine and Vanni, 2002) showed that the $\mathrm{N}$ and $\mathrm{P}$ fluxes excreted by chironomids in Lake Garças were approximately one order of magnitude lower than those reported for eutrophic lakes in temperate zones.

When evaluating the mass balance of chemical elements in lakes and reservoirs, one must keep in mind that not only the external inputs such as point and nonpoint sources from the watershed are involved but also other sources of nitrogen and phosphorus input such as internal loads and rainfall. The contribution from rainfall is insignificant in Lake Garças, since it corresponds to only 1 and $0.1 \%$ of the total external inputs of nitrogen and phosphorus, respectively (Henry et al., 2004). With regard to internal loads, the role of nutrients excreted into the water column by organisms such as zooplankton (Lenz et al., 1986; Wen and Peters, 1994; Pinto-Coelho and Greco, 1999), fishes (Persson, 1997; Schaus et al., 1997) and benthic invertebrates (Covich et al., 1999; Vanni, 2002), and of the fluxes of elements from sediment to water (Starkel, 1985; Fukuhara and Sakamoto, 1987; Vanni, 2002) is extremely important for the ecology of aquatic ecosystems.

In Lake Garças, the contribution of Chironomidae to internal loads appears to be low, since only $25 \%$ of the total mesobenthic fauna density is composed of these insect larvae (Santos, 2002). The phosphate and ammonium rates excreted by Chironomus organisms are only significant when the total density of Chironomidae is $>780$ ind. $\mathrm{m}^{-2}$ (Table 1). Considering the mean biomass $\left(34 \mathrm{mg} \cdot \mathrm{m}^{-2}\right)$ of chironomids, the lake's area $\left(88,156 \mathrm{~m}^{2}\right)$ and the mean phosphate and ammonium excretion rates (2.01 and $1.64 \mathrm{mg} \cdot \mathrm{m}^{-2} / \mathrm{day}$, respectively), the contribution of benthic Chironomidae to the lake's internal loads in October-November 1998 would be $181 \mathrm{Kg} \mathrm{P}$ and $147 \mathrm{Kg}$ $\mathrm{N}$. Since the mean monthly inputs are $543 \mathrm{Kg} \mathrm{P}$ and 
3,096 Kg N (estimated from annual loads, Henry et al., 2004), the internal loads contributed by Chironomus correspond to $33 \%$ of the external phosphorus loads and to only $5 \%$ in the case of nitrogen.

In a long-term study, Bicudo et al. (2006) found that, after the June-September 1999 removal of Eichhornia crassipes (Mart.) Solms that covered 40 to $70 \%$ of Lake Garças, the lake's trophic status shifted from a eutrophic state (from April 1998 to August 1999) to a hypereutrophic condition (from September 1999 to date). This change in the lake's trophic state in response to the mechanical removal of the floating macrophytes was confirmed by an increase in the mean concentrations of total phosphorus, chlorophyll and $\mathrm{pH}$ in the surface water, and a reduction in water transparency and free $\mathrm{CO}_{2}$ (Bicudo et al., 2006). The removal of E. crassipes caused other modifications in the limnology of the aquatic ecosystem, such as an increase in the lake's physical stability due to the heating of the water column; an increase in its relative thermal resistance to mixing; in the duration of thermal stratification and in the period of anoxia at the bottom of the lake (Bicudo et al., 2006).

Considering the recent changes in the quality of the water of Lake Garças, a logical assumption would be an increase in ammonium and phosphate excretion rates due to the rise in water temperature. However, a more probable outcome would be a reduction in the release rates as a result of the more frequent and longer periods of anoxia at the lake bottom. Devine and Vanni (2002) reported that a comparison of three sites in Lake Acton (in the inflow zone of the tributaries, in the middle and in the dam zones) revealed a reduction in the nitrogen and phosphorus excretion by Chironomidae from the upstream to the downstream reservoir from June to November. This decrease in the fluxes was attributed to the oxygen condition - anoxia - at the bottom from May to September. Thus, the mechanical removal of Eichhornia crassipes from the surface of Lake Garças has, in recent years, led to an increase in the total phosphorus and "reactive" soluble phosphorus due to the diffusion of phosphorus from interstitial water in the sediment to the layer above the bottom of the lake, and the participation of Chironomidae in the internal loads is probably insignificant.

Acknowledgements - The authors are grateful to Bicudo, D. and Bicudo, C. for the facilities in field and laboratory, to Ramos, J. in preparing the manuscript, to Rodrigues, H. in the field sampling and to Ballain, B. for the English revision of the paper. C.M. dos Santos received a scholarship from FAPESP (Proc. 97/0646-8; Proc. 97/10213-7).

\section{References}

ANDERSSON, G., GRANÉLI, W. and STENSON, J., 1988. The influence of animals on phosphorus cycling in lake ecosystems. Hydrobiologia, vol. 170, no. 1, p. 267-264.

BICUDO, CEM., CARMO, CF., BICUDO, DC., HENRY, R., PIÃO, ACS., SANTOS, CM. and LOPES, MRM., 2002.
Morfologia e morfometria de três reservatórios do PEFI. In BICUDO, DC., FORTI, MC. and BICUDO, CEM. (Eds.). Parque Estadual das Fontes do Ipiranga: unidade de conservação ameaçada pela urbanização de São Paulo, SP: São Paulo. Secretaria do Meio Ambiente de São Paulo.

BICUDO, DC., FONSECA, BM., BICUDO, CEM., BINI, LM. and JESUS, TA., 2006. Remoção de Eichhornia crassipes em um reservatorio tropical raso e suas implicações na classificação trófica do sistema: estudo de longa duração no Lago das Garças, São Paulo, Brasil. In TUNDISI, JG., MATSUMURATUNDISI, T. and SIDAGIS-GALLI, CU. (Eds.). Eutrofização na América do Sul: causas, consequências e tecnologias para gerenciamento e controle. Instituto Internacional de Ecologia, São Carlos, SP.

BICUDO, DC., FORTI, MC., CARMO, CF., BOUROTTE, C., BICUDO, CM., MELFI, AJ. and LUCAS, Y., 2002. A atmosfera as águas superficiais e os reservatórios no PEFI: caracterização química. In BICUDO, DC., FORTI, MC. and BICUDO, CEM. (Org.). Parque Estadual das Fontes do Ipiranga. Unidade de Conservação que resiste à urbanização de São Paulo. São Paulo, SP: Ed. Secretaria do Meio Ambiente do Estado de São Paulo.

BRINKHURST, RO. and MARCHESE, MR., 1991. Guia para la identificación de oligoquetos acuáticos continentales de Sud y Centroamérica. Argentina: Associación de Ciências Naturales Del Litoral. 207 p.

COVICH, AP., PALMER, MA. and CROWL, TA., 1999. The role of benthic invertebrate species in freshwater ecosystems. BioScience, vol. 49, no. 2, p. 119-127.

DEVINE, JA. and VANNI, MJ., 2002. Spatial and seasonal variation in nutrient excretion by benthic invertebrates in a eutrophic reservoir. Freshwater biology, vol. 47, no. 6, p. $1107-1121$.

EPLER, JH., 1992. Identification manual for the larval Chironomidae (Diptera) of Florida. Orlando: Dept. of Environment Regulation. 308 p.

FUKUHARA, H. and YASUDA, K., 1985. Phosphorus excretion by some zoobenthos in a eutrophic freshwater lake and its temperature dependency. Japanese Journal of Limnology, vol. 46, no. 4, p. 287-296.

-, 1989. Ammonium excretion by some freshwater zoobenthos from a eutrophic lake. Hydrobiologia, vol. 173, no. 1, p. 1-8.

FUKUHARA, H. and SAKAMOTO, M., 1987. Enhancement of inorganic nitrogen and phosphate release from lake sediment by tubificid worms and Chironomid larvae. Oikos, vol. 48, no. 3, p. 312-320.

GALLEPP, GW., 1979. Chironomid influence on phosphorus release in sediment-water microcosms. Ecology, vol. 60, no. 3, p. $547-556$

GARDNER, WS., NALEPA, TF., QUIGLEY, MA. and MALCZYK, JM., 1981. Release of phosphorus by certain benthic invertebrates. Canadian Journal of Fisheries and Aquatic Sciences, vol. 38, p. 978-981.

GARDNER, WS., NALEPA, TF., SLAVENS, DR. and LAIRD, GA., 1983. Patterns and rates of nitrogen release by benthic Chironomidae and Oligochaeta. Canadian Journal of Fisheries and Aquatic Sciences, vol. 40, no. 3, p. 259-266. 
GRANÉLI, W., 1979. The influence of Chironomus plumosus larvae on the exchange of dissolved substances between sediment and water. Hydrobiologia, vol. 66, no. 2, p. 149-159.

HENRY, R. and STRIPARI, NL., 2005. The invertebrate colonization during decomposition of Eichhornia crassipes in the mouth zone of Guareí River into Jurumirim Reservoir (São Paulo, Brazil). The Ekologia, vol. 3, no. 2, p. 01-12.

HENRY, R., 1999. Heat budgets, thermal structure and dissolved oxygen in Brazilian reservoirs. In TUNDISI, JG. and STRASKRABA, M. (Eds.). Theoretical Reseroir Ecology and its applications. International Institute of Ecology, Brazilian. Academy of Sciences and Backhuys Publishers.

HENRY, R., CARMO, CF. and BICUDO, DC., 2004. Trophic status of a Brazilian urban reservoir and prognosis about the recovery of water quality. Acta Limnologica Brasiliensia, vol. 16, no. 3, p. 251-262.

LEHMAN, JT., 1980. Release and cycling of nutrients between planktonic algae and herbivores. Limnology and Oceanography, vol. 25 , no. 4 , p. 620-632.

MASON-Jr., WT. and YEVICH, PP., 1967. The use of Phloxine $\mathrm{B}$ and Rose Bengal stains to facilitate sorting of benthic samples. Trans of American Microscopy Societies, vol. 86, no. 2, p. 221-223.

MERCANTE, CTJ. and TUCCI-MOURA, A., 1999. Comparação entre os índices de Carlson e de Carlson modificado aplicado a dois ambientes subtropicais, São Paulo, SP. Acta Limnologica Brasiliensia, vol. 11, no. 1, p. 1-14.

MERRIT, RM. and CUMMINS, KW., 1996. An introduction to the aquatic insects of North America. Dubuque, Kendall/Hunt. $862 \mathrm{p}$.

NALEPA, TF., GARDNER, WS. and MALCZYK, JM., 1983. Phosphorus release by three kinds of benthic invertebrates: effects of substrate and water medium. Canadian Journal of Fisheries and Aquatic Sciences, vol. 40, p. 810-813.

NOGUEIRA, NMC. and RAMIREZ, RJJ., 1998. Variação mensal da condição trófica do Lago das Garças (São Paulo, SP, Brasil). Acta Limnologica Brasiliensia, vol. 10, no. 2, p. 21-34.

PERSSON, A., 1997. Phosphorus release by fish in relation to external and internal load in a eutrophic lake. Limnology and Oceanography, vol. 42, no. 3, p. 577-583.

SANTOS, CM., 2002. Distribuição de mesoinvertebrados em um lago eutrofizado (Lago das Garças - SP) e excreção de fosfato e amônio por Chironomidae (Díptera). (Tese de doutorado) Instituto de Biociências, UNESP, Botucatu, SP.
SANTOS, PM. and FUNARI, F., 2002. Clima local. In BICUDO, DC., FORTI, MC. and BICUDO, CEM. (Org.). Parque Estadual das Fontes do Ipiranga. Unidade de Conservação que resiste à urbanização de São Paulo. São Paulo, SP: Ed. Secretaria do Meio Ambiente do Estado de São Paulo.

SCHAUS, MH., VANNI, MJ., WISSING, TE., BREMIGAN, HT., GARVEY, JE. and STEIN, RA., 1997. Nitrogen and phosphorus excretion by detritivorous gizzard shad in a reservoir ecosystem. Limnology and Oceanography, vol. 42, no. 6 , p. 1386-1397.

SNEDECOR, GW. and COCHRAN, WG., 1978. Statistical methods. Iowa, USA. $593 \mathrm{p}$.

STARKEL, WM., 1985. Predicting the effect of macrobenthos on the sediment/water flux of metals and phosphorus. Canadian Journal of Fisheries and Aquatic Sciences, vol. 42, p. 95-100.

STRIPARI, NL. and HENRY, R., 2002. The invertebrate colonization during decomposition of Eichhornia azurea Kunth in a lateral lake in the mouth zone of Paranapanema River into Jurumirim Reservoir (São Paulo, Brazil). Braz. J. Biol. $=$ Rev. Bras. Biol., vol. 62, no. 2, p. 293-310.

TARVAINEN, M., VENTELÄ, AM., HELMINEN, H. and SARVALA, J., 2005. Nutrient release and resuspension generated by ruffe (Gymnocephalus cernuus) and chironomids. Freshwater Biology, vol. 50, no.3, p. 447-458.

TÁTRAI, I., 1986. Rates of ammonia release from sediments by chironomid larvae. Freshwater biology, vol. 16, no. 1, p. 61-66.

TOKESHI, M., 1995. Life cycles and population dynamics. In ARMITAGE, P., CRANSTON, PS. and PINDER, LCV. (eds.). The Chironomidae biology and ecology of non-biting midges. London: Chapman and Hall.

TOLEDO-Jr., AP., TALARICO, M., CHINEZ, SJ. and AGUDO, EG., 1983. A aplicação de modelos simplificados para a avaliação e processo de eutrofização em lagos e reservatórios tropicais. In Anais do $12^{\circ}$ Congresso Brasileiro de Engenharia Sanitária, Camburiú-SC.

TRIVINHO-STRIXINO, S. and STRIXINO, G., 1995. Larvas de Chironomidae (Diptera) do Estado de São Paulo: Guia de identificação e diagnose dos gêneros. PPG-ERN/UFSCAR, São Carlos. 229 p.

VANNI, MJ., 2002. Nutrient cycling by animals in freshwater ecosystems. Annual Revue of Ecology and Systematics, vol. 33 , no. único, p. 341-370.

VIEIRA, S., 1999. Estatítica experimental. $2^{a}$ ed. São Paulo: Ed. Atlas S.A. 185 p. 